\title{
Colonia Patricia (Corduba), capital de la Bética
}

\author{
Juan Francisco RodRíguez NeILA \\ Universidad de Córdoba \\ ca1ronej@uco.es
}

\section{RESUMEN}

La primera etapa histórica de Corduba en época republicana terminó dramáticamente con su destrucción al final de la guerra civil entre cesarianos y pompeyanos. Pero durante el gobierno de Augusto la ciudad salió de su postración, ostentando la capitalidad de la nueva provincia Hispania Ulterior Baetica. Signos de los nuevos tiempos bajo el régimen imperial fueron una radical remodelación urbana, dos deductiones coloniales que revitalizaron su población, un papel económico destacado, en el contexto de una red renovada de comunicaciones, y una sociedad muy cambiada, para la que se abrieron nuevos horizontes de riqueza y promoción personal. Tales son los aspectos fundamentales tratados en este trabajo.

Palabras clave: Augusto. Corduba. Baetica. Sociedad. Economía. Urbanismo.

\section{Colonia Patricia (Corduba), Capital of Baetica}

\begin{abstract}
This paper approaches the developments of Corduba during the reign of Augustus, when its situation changed dramatically after a first Republican historical span which had ended with the destruction of the city at the end of the civil war between Caesarians and Pompeians. During Augustus' rule of Rome, Cordu$b a$ became the capital of the new province of Hispania Ulterior Baetica. With this development, the city experimented a radical urban restructuring, two colonial deductiones which revitalized its population, and a prominent role of the economy in the middle of an invigorated communication network. The turn also had deep effects in the social fabric, where new horizons of change, wealth an individual promotion were opened.
\end{abstract}

Key Words: Augustus. Corduba. Baetica. Society. Economy. Urbanism.

Sumario: 1. La "refundación" de la ciudad. 2. La capitalidad de la provincia Bética. 3. La red de comunicaciones. 4. Sociedad y actividades económicas. 5. El renacimiento urbanístico. 
La historia de Corduba tuvo un "antes" y un "después", marcados por un hito trágico, la gran catástrofe que sufrió en marzo del 45 a.C., al final de la "guerra de Munda", a raíz del asalto cesariano y el incendio de la ciudad, con un terrible saldo de veintidós mil muertos. ${ }^{1}$ Fue el precio que pagó por haber apoyado la causa pompeyana. ${ }^{2}$ Así se cerró una primera etapa histórica tras su fundación, que el geógrafo Estrabón atribuye al consular romano Claudio Marcelo, ${ }^{3}$ en una de sus dos estancias en Hispania, como pretor de las provincias Citerior y Ulterior en el 169/168, y como legado proconsular en la Citerior en el 152/151 a.C. ${ }^{4}$ Sin embargo la indicación del geógrafo griego sobre el carácter inicial de dicho asentamiento, al que califica de apoikia, ha sido muy discutida. ${ }^{5}$ Sí está claro que surgió junto a un previo oppidum indígena turdetano bien documentado por la Arqueología, que se consolidó en el Bronce Final, y que convivió durante un tiempo con el nuevo establecimiento romano, quizás hasta inicios del siglo I a.C. Estrabón dice también que fue poblada inicialmente por un contingente mixto de romanos e indígenas, a los que califica de "selectos", aunque no está claro en qué consistió tal cualidad. Elementos de la aristocracia autóctona de dicho poblado y quizás de otras comunidades vecinas pudieron configurar el núcleo de "nativos" selectos. En cuanto a los romaioi "selectos", es un concepto amplio e integrador. Pudo tratarse de un conjunto heterogéneo, no sólo ciudadanos romanos "stricto sensu", sino también aliados itálicos que habían formado parte de los auxilia del ejército de ocupación, e incluso hybridae resultado de las uniones entre soldados romanos y mujeres indígenas. ${ }^{6}$

Otra cuestión importante y discutida es qué estatuto jurídico tuvo desde sus inicios. La opinión más generalizada es que fue colonia latina, ${ }^{7}$ en cuyo seno hubo un conventus civium Romanorum, cuya existencia está documentada por las fuentes literarias en tiempos de las guerras civiles entre cesarianos y pompeyanos. ${ }^{8}$ Dicha condición debió de mantenerse hasta tiempos de César o Augusto.

La nueva fundación romana se asentó sobre una elevación, desde la que se dominaban los vados del Baetis y las fértiles tierras vecinas. Era un lugar seguro, con buenas condiciones topográficas para su defensa, y en una encrucijada de importantes rutas terrestres y fluviales, que le daban acceso directo a áreas de gran riqueza minera, agrícola y ganadera y la conectaban con Lusitania y la Meseta. Todo ello le permitió ir ejerciendo destacadas funciones administrativas y económicas dentro de la provincia Hispania Ulterior. Pero también, como otras tempranas creaciones urbanas de Roma en Hispania

1 BH, 34 .

2 Sobre el papel de Corduba en dicho conflicto: RodRíGUEz NeILA 2005.

3 Estrab., 3.2.1.

4 También se le ha identificado con Marcelo, sobrino y yerno de Augusto (CANTO 1991, 1997).

5 Vid. una reciente discusión del tema en García Fernández 2014.

6 Para estas cuestiones concretas, y para todo lo relativo a la historia de la ciudad en épocas republicana e imperial, remito a las visiones globales de: KNAPP 1983; RoDríGUEZ NeILA 1988, 1992; DuPRÉ 2004; JiMÉNEZ CARrillo 2011.

7 Estatuto que tuvo Carteia, fundada no muchos años antes, también con una población mixta (Liv., 43.3.1-4). Los cordubenses adscritos a la tribu Sergia pudieron ser descendientes de los latinos y peregrinos que durante la República habrían podido acceder a la ciudadanía romana, o de quienes formaron parte de la deductio cesariana. Vid. al respecto: KNAPP 1983, 11 ss; Wiegels 1985, 30 ss; Stylow 1995, 1996; GARCía Fernández 2002; Rodríguez NeIla 2005, 317 ss; Beltrán 2011.

8 Sobre el conventus c.r. de Corduba: Rodríguez NeIla 2005, 320-325. 
(Italica, Carteia, Gracchurris, etc.), surgió por necesidades de la presencia militar. Son frecuentes las referencias a Corduba como asentamiento de tropas y lugar de partida de expediciones militares durante los siglos II-I a.C., dada también su condición de sede oficiosa del gobernador romano. ${ }^{9}$

\section{La "refundación" de la ciudad}

Pese a su apoyo a la causa pompeyana, y valorándose más su estratégica posición geográfica, y el papel político y económico que podía tener en la nueva etapa imperial, Corduba iría pasando de la postración a la recuperación en los tiempos posteriores al final de las guerras civiles. Y con una imagen renovada, ya que cambiaría su nombre, su estatuto jurídico, buena parte de su población y su configuración urbana y monumental.

En primer lugar, para compensar las enormes pérdidas demográficas causadas por la guerra civil, fue repoblada. Posiblemente la doble tribu atestiguada entre sus habitantes refleje dos deductiones. La primera debió de tener lugar en época de César, no mucho tiempo después de su destrucción, cuando seguía siendo colonia latina. ${ }^{10} \mathrm{Se}$ efectuaría con soldados licenciados de las guerras civiles, y en el marco del gran programa de colonización previsto por el dictador en Hispania, ejecutado en la Ulterior por el gobernador Asinio Polión (44-43 a.C.), como documenta el nuevo bronce de Urso. ${ }^{11}$ En el caso concreto de Corduba sería deductor de la que, quizás desde entonces, se convirtió en colonia civium Romanorum, cuyos nuevos moradores quedaron adscritos a la tribus Sergia.

Confirmación indirecta del acto de fundación podría ser un fragmento de lastra campana hallado en Córdoba, cuya producción se realizaba por aquella época precisamente en talleres itálicos propiedad de Asinio Polión. En ella aparecen representaciones de aves relacionadas con fórmulas del ius auguralis, por lo que pudo formar parte del auguraculum ubicado extramuros al oeste de la ciudad, donde habría tenido lugar en el 43 a.C. el ritual de inauguratio de la nueva Colonia Patricia. ${ }^{12}$

Más tarde la ciudad recibió una nueva deductio con licenciados de las guerras cántabras, posiblemente en el 19 a.C., por obra de M. Agripa, la cual sería refrendada por Augusto durante su estancia en Hispania el 13 a.C. Esos nuevos colonos, quizás en buena parte de la legio I Augusta, y a quienes se repartirían tierras sobrantes de la deductio cesariana, fueron asignados a la tribus Galeria. ${ }^{13}$ Se ha podido identificar epigráficamente a uno, L. Manlius Bocchus, tribuno militar de la legio XVI Gallica en las campañas de Agripa en el Norte. ${ }^{14}$ Tras su servicio militar ejerció como duunviro y prefecto en la administración colonial, cuyo cuadro institucional no debió de diferir

9 Vid. al respecto RodRíGuEZ NeILA 1992.

10 Cfr. Ventura 2009, 377 ss; 2011, 33-39.

11 LCGI, 15. Vid. Caballos 2006, 338-376, para la actividad de Asinio Polión en la Hispania Ulterior y la fundación de colonias.

12 Vid. Ventura 2006.

13 Cfr. García y Bellido 2006; Ventura 2011, 39 ss.

14 CIL II $2 / 7$, 284. Cfr. Ventura 2009, 385-388. 
mucho del que, por el mismo tiempo, recibió la colonia Genetiva Iulia, cuyo estatuto conocemos parcialmente, pues fue grabado en tablas de bronce.

Otra novedad importante fue el cambio de nombre. Se abandonó, al menos oficialmente, el de Corduba, de origen nativo, y pasó a denominarse Colonia Patricia. Este epíteto, Patricia, con el que fue sin duda honrada, ha sido objeto de distintas interpretaciones. Pudo recibirlo en honor de Julio César, en su condición de deductor perteneciente a una familia patricia descendiente de Rómulo, fundador de Roma. ${ }^{15}$ Testimonio del cambio onomástico son unas acuñaciones conmemorativas con permiso imperial, emitidas hacia el 12 a.C. o poco más tarde, en las que aparece por primera vez el nuevo nombre que reemplazaba al viejo topónimo indígena, así como signa militaria alusivos a la deductio efectuada con licenciados de la milicia. ${ }^{16}$

En esa época pudo completarse también la reorganización administrativa y fiscal de su territorium. Las intervenciones de Augusto en su ordenamiento político y social pueden apreciarse también en otros hechos, tales como la concesión o ratificación del título colonial y el asentamiento de soldados. La amplitud y recursos de su suelo fueron destacados en aquel tiempo por Estrabón, quien señala que abarcaba un amplio trecho del Baetis, lo que le aseguraba recursos agrícolas. ${ }^{17}$ Pero en su mayor parte se extendía hacia el norte por Sierra Morena, donde además de importantes yacimientos mineros habría extensas zonas de pascua y silvae, y aprovechamiento ganadero. ${ }^{18}$ Ya en época cesariana pudo efectuarse una centuriatio del mismo, que sería parcial, pues hubo una nueva deductio bajo Augusto. Su ordenamiento implicaría la definitiva fijación de sus fronteras y la articulación del sistema de propiedad del suelo en fundi y pagi, ${ }^{19}$ así el Pagus Augustus documentado epigráficamente, pero cuya ubicación desconocemos. ${ }^{20}$ Los pagi tenían una funcionalidad administrativa, económica, censual y fiscal ${ }^{21}$ siendo muy probable que esta práctica catastral se usara en Hispania ya desde tiempos de Augusto en las áreas coloniales o al menos más romanizadas. ${ }^{22}$

\section{La capitalidad de la provincia Bética}

Aunque ninguna fuente testimonia directamente que Corduba fuera capital de la Hispania Ulterior durante la República, sí parece haber asumido oficiosamente dicha con-

\footnotetext{
15 Es posible que la ciudad no llevara el cognomen Iulia o Augusta, porque los veteranos asentados en ella pertenecieron principalmente a la legio I Augusta, degradada el mismo año 19 a.C. Cfr. GARCÍA y Bellido 2006, 256-258; VeNTURA 2009, 387.

16 Sobre esta emisión monetal: Chaves 1977; García y Bellido 2006.

17 Estrab., 3.2.1.

18 Sobre la extensión y fronteras del territorium asignado a Colonia Patricia: KNAPP 1983, 36-39; CoRTIJO 1993, 216-218; MELCHOR 2004; RodRíGUEZ SÁNCHEZ 2008. La parte serrana pudo llegar por el norte hasta las zonas de Espiel y Alcaracejos (Cerro del Germo).

19 La Tabula Alimentaria de Velleia (CIL XI, 1, 1147= ILS 6675, 103-112 d.C.), por ejemplo, nos presenta el pagus y el fundus como las dos unidades básicas de la organización territorial de una ciudad.

20 Se trata de una dedicación al genius pagi $\left(C I L \mathrm{II}^{2} / 7,231\right)$.

21 Cfr. Dig., 50.15.4, praef., Ulp.

22 Vid. al respecto CURChin 1985, 342 ss; Cortijo 1993, 227-241; TARPIN 2002, 195-202.
} 
dición, siendo quizás residencia ordinaria del gobernador desde fines del siglo II a.C. ${ }^{23}$ Tras la catástrofe del 45 a.C. no parece que perdiera tal condición. Poco después de finalizar el conflicto entre cesarianos y pompeyanos la correspondencia del gobernador Asinio Polión con Cicerón en el 44-43 a.C. está datada en Corduba, desde donde partían los correos hacia Roma. ${ }^{24}$ Pero sería Augusto quien, en el marco de la gran reforma provincial efectuada en Hispania, y seguramente durante su estancia en 15-13 a.C., convertiría a Colonia Patricia en capital oficial de la nueva Hispania Ulterior Baetica, que pasó a depender del Senado y pueblo de Roma. ${ }^{25}$ A dicha cualidad se sumaría la de capital de uno de los cuatro conventus jurídicos en que quedó subdividida la provincia. ${ }^{26}$ Las temporales estancias de los gobernadores y funcionarios de la administración imperial debían atraer mucha gente hasta Corduba, con apreciables ganancias para sus moradores, al generarse una demanda especial de productos y servicios. ${ }^{27}$ Ese contacto directo y frecuente sería especialmente provechoso para la aristocracia local.

Cuando no lo hacía en la capital el procónsul impartía justicia en las periódicas giras por su demarcación recorriendo las sedes de los conventus. ${ }^{28}$ En el caso del conventus cordobés, abarcaba el valle medio del Guadalquivir hasta la confluencia con el Genil, penetraba muy poco en la campiña al sur, pero sobre todo se extendía profundamente hacia el norte por Sierra Morena. ${ }^{29}$ Su definición espacial con una capital situada en posición casi tangencial, tuvo más que ver con los intereses económicos y su ubicación en la red de comunicaciones. Los territorios montañosos del conventus Cordubensis formaron parte del Mons Marianus, zona de conexión entre el valle del Guadalquivir y la Meseta-Extremadura, de la que formaba parte la Baeturia túrdula, uno de los principales cotos mineros de la Hispania romana. ${ }^{30}$

En su nueva condición de capital provincial, Colonia Patricia pasó a ser sede estable del procónsul romano. ${ }^{31}$ Para un senador con aspiraciones la Bética debía de ser un destino apetecido porque daba prestigio. Entre quienes la gobernaron hubo mayoría de senadores de cursus honorum modesto, sobre todo en época julio-claudia. Pero también la rigieron algunos personajes importantes, con gran proyección, que realizaron una brillante carrera política, culminada a menudo con el consulado. Pero conocemos pocos. ${ }^{32}$ Para época de Augusto tenemos como testimonio el juramento de fidelidad a la casa imperial realizado por los magistrados, senado y pueblo de Conobaria entre el 6-5

\footnotetext{
23 Vid. Haensch 1997. Cfr. BH, 3.

24 Cic., ad Fam. X 31.5; 31.6; 32.5. Vid. CABAllos 2006, 346-360.

25 Estrab., 17.3.25; Dio Cas., 53.12.4-5. Pomponio Mela también destacó a Corduba como la más importante ciudad de la Bética, junto a Hispalis y Astigi (Chor., 72).

26 Plin., NH 3.7. Sobre los conventus jurídicos: SANCHO 1978; Dopico 1986.

27 Así lo señala Dión de Prusa (Or, 35.15) con relación a los conventus de Asia, donde acudían jueces, reos, oradores, comerciantes, maleantes, prostitutas, etc.

28 Vid. Marshall 1966; Burton 1975; Bérenger-Badel 2003; Saquete 2006.

29 Cortijo 1993, 144 ss.

30 Autores como Estrabón (3.2.3) o Plinio (NH 3.13-14) la describen como una región árida y montañosa, situada más allá de las tierras septentrionales del valle del Baetis, y que se extendía hasta el río Anas.

31 Sobre Colonia Patricia como centro administrativo de la provincia Bética: RodríGUEz NeILA 2009.

32 Cfr. Navarro 2004. Vid. Szramkiewicz 1975-1976, para los gobernadores provinciales de época augustea.
} 
a.C. Aparece encabezado por uno de los pocos procónsules documentados, P. Petronius Turpilianus. ${ }^{33}$

Entre sus diversas funciones correspondía al gobernador el control de las finanzas municipales. Pero desconocemos con qué frecuencia y profundidad podían efectuar tales "auditorías", para la Bética carecemos de información. ${ }^{34}$ Según el jurista Ulpiano tenían competencias sobre la red viaria principal, edificios públicos y templos de las ciudades, que debían inspeccionar periódicamente para comprobar si estaban en buen estado o necesitaban reparación. ${ }^{35}$ Tal supervisión obedecía tanto a razones económicas, para evitar derroches o uso fraudulento del dinero público, como a criterios de seguridad, al ser recintos que acogían multitudes. ${ }^{36}$ Posiblemente, al residir largo tiempo en Colonia Patricia, los procónsules ejercerían una supervisión más directa sobre los proyectos edilicios en ella desarrollados, teniendo en cuenta el gran esplendor monumental que fue adquiriendo desde Augusto, y que dicha transformación urbanística pudo ser financiada no sólo con recursos municipales y aportaciones evergéticas, sino con fondos imperiales cuya gestión tendría que ser fiscalizada. ${ }^{37}$

El gobernador de la Bética contaba con un equipo, donde figuraban como principales colaboradores el legatus proconsulis y el quaestor, cargos reservados a miembros del orden senatorial. Los legados actuaban por delegación de su superior, y asumían las tareas que aquél les asignaba, especialmente las judiciales. ${ }^{38}$ En cuanto al quaestor, nombrado por el Senado, gestionaba el aerarium o caja provincial y el cobro de impuestos. Pocos tenemos documentados, y apenas sabemos de su gestión. ${ }^{39}$ Bajo Augusto o Tiberio ejerció como tal Sex. Curvius Silvinus, nombrado hospes publicus por los habitantes de Munigua. ${ }^{40} \mathrm{Y}$ en el citado juramento pro salute Augusti de Conobaria figura, junto al nombre del procónsul, el de M. Alfius Laches, posiblemente su cuestor. En Colonia Patricia recalaron también funcionarios del servicio imperial, como los procuratores responsables de áreas fiscales concretas y de la gestión del patrimonio del emperador en la provincia. ${ }^{41}$ Algunos de los que conocemos procedían de las mismas élites municipales de la provincia. ${ }^{42}$ En los cotos mineros del conventus Cordubensis ejercería su jurisdicción el procurator Montis Mariani. ${ }^{43}$ En la capital bética radicaban asimismo las oficinas de la burocracia provincial y otras dependencias, por ejemplo las sedes del

33 Documento hallado cerca de Cabezas de San Juan-Sevilla-(AEp 1988, 723=HEp 2, 623; 5, 694). Vid. GonZÁlez 1988; CASTILlo 1994.

34 Tenemos más documentación sobre esta cuestión para la parte oriental del Imperio. Vid. BuRTON 2004, 318 ss.

35 Cfr. Dig. 1.16.7.1; 50.10.3. Sobre tales competencias BuRTON 2004, 325 ss.

36 Dicha cuestión está bien documentada por las fuentes epigráficas, pero en la parte oriental del Imperio (Burton 2004, 328 ss). Vid. al respecto Plin., Ep. X, 23, 37, 39, 90 y 98.

37 Vid. al respecto Joufrroy1986. En Colonia Patricia pudo ser el caso de los acueductos -Aqua Vetus, Aqua Nova Domitiana Augusta-, de los foros o de los grandes edificios para espectáculos. Recordemos que Augusto menciona en sus Res Gestae (16) la ayuda financiera que prestó a las colonias.

38 Dig., 1.16.4.6; 1.16.6.2; 1.16.11-13 y 15. Vid. al respecto NAVARRo 2007.

39 Vid. AlFÖLDY 1969, 180-183, 279-282; KNAPP 1981.

40 AEp 1962, 287.

41 Vid. BuRTON 1993, y OJEDA 1994, para quienes ejercieron procuratelas en la Bética.

42 Caballos 1995, 1998.

43 CIL II, 1179 (Hispalis). Con este funcionario estaría conectado el procurator massae Marianae documentado en un epígrafe de Ostia (CIL XIV, 52). 
aerarium (tesoro) y archivo (tabularium) ${ }^{44}$ También era lugar de anuncio de documentos importantes expedidos desde Roma. ${ }^{45}$

\section{La red de comunicaciones}

La gestión administrativa de la Bética en época alto-imperial fue facilitada por una red de comunicaciones que experimentó notables mejoras desde Augusto, quien le prestó específica atención. Para tomar el pulso a su demarcación los gobernadores debían pasar un tiempo viajando por su circunscripción. ${ }^{46}$ Por ello su actividad dependía mucho de las vías terrestres y fluviales. Pero también los procónsules y demás funcionarios a sus órdenes debían mantener activa correspondencia con el emperador, para mantenerle al tanto de lo que ocurría en la provincia o consultarle sobre diversos asuntos. Por ello fue muy importante la conexión con Roma a través de correos oficiales. En época republicana el gobernador de la Ulterior tenía sus propios mensajeros, tabellarii y statores. Como los tabellarii que usó Asinio Polión en el 44-43 a.C., para enviar desde Corduba cartas a Roma. ${ }^{47}$ Augusto, que se ocupó de mejorar la red viaria del Imperio, organizó también el cursus publicus. ${ }^{48}$

Pero Colonia Patricia fue igualmente en época de Augusto centro de gran actividad mercantil, que debió mucho a su estratégica situación en la red de comunicaciones. ${ }^{49}$ En ella convergían la Via Augusta y otras importantes calzadas terrestres, que la comunicaban hacia el oeste con Hispalis y Gades, hacia el este con Castulo, hacia el norte con Emerita, capital de la Lusitania, y Toletum, y hacia el sur con Iliberris, Anticaria y Malaca. También el cursus publicus utilizaba principalmente las denominadas viae militares, consideradas de interés estratégico, bien construidas y dotadas de puentes para facilitar los desplazamientos de los vehículos. Tal condición tuvo la Via Augusta, que conectaba la capital de la Bética no sólo con la Urbs, sino también con las otras sedes de conventus..$^{50}$ Por ello fue sostenida con financiación imperial y se realizaron obras de mantenimiento con regularidad. Inaugurada el 2 a.C., como documentan algunos miliarios, ${ }^{51}$ supuso un beneficio muy importante para la ciudad.

44 Vid. HAENSCH 1992, sobre los archivos provinciales y las clases de documentos que guardaban. Un liberto imperial que ejerció como tabularius de la prouincia Baetica, está documentado en Colonia Patricia $\left(C I L \mathrm{II}^{2} / 7\right.$, 290).

45 Como fue el caso del senadoconsulto sobre las honras fúnebres en memoria de Germánico, cuyo contenido se ha conservado en la Tabula Siarensis (SÁNCHEZ - Ostiz 1999), o del senadoconsulto de Cn. Pisone patre, donde se prescribe que debía ser publicado en la ciudad más importante de la provincia, urbs celeberruma (CABALLOS ECK 1996).

46 Un ejemplo fue Cicerón, que nos ha dejado abundante información sobre sus viajes cuando gobernó Cilicia (MuÑIZ 1998). Vid. también CHEVALliER 1988, 157 ss.

47 Cic., ad Fam. X 31 y 33.

48 Suet., Aug. 49, 5 y 50. Lo hizo buscando más la seguridad del correo que su rapidez, siempre limitada con los medios de comunicación de entonces. El servicio postal usaba mensajeros que, provistos de credenciales (Plin., Ep. X, 45.64-67), iban a caballo, o bien en vehículos ligeros (redhae) o pesados. Vid. al respecto: CHEVALLIER 1972, 207 SS; RAmieri 1996; Di PaOla 1999; Crogiez 2002.

49 Vid. sobre el tema: Sillières 1990; MELCHOR 1995.

50 Cfr. SilliÈres 1990, 783 ss.

51 Sillières 1990,103 n. 42; 107 n. 46; 107-108 n. 48. 
Por lo que respecta a la calzada Corduba-Metellinum, que cruzaba el Mons Marianus continuando hasta Emerita ${ }^{52}$ tuvo una importante función económica, pues por ella se transportaba la producción minera serrana para darle salida por el puerto fluvial del Baetis, o llegaban las importaciones destinadas al consumo de los poblados mineros. ${ }^{53}$ Desde Augusto, época en la que fue seguramente mejorada, tuvo asimismo gran importancia administrativa, pues permitía al gobernador de la Bética mantener contacto con el legado imperial de Lusitania.

Otra calzada que atravesaba importantes áreas mineras del Mons Marianus y, por tanto, tuvo también importante función económica, fue la que conectaba Corduba con Sisapo. ${ }^{54}$ No es citada en ningún itinerario, pero era una vía necesaria para dar salida sobre todo al apreciado minium. ${ }^{55}$ Una inscripción, posiblemente de la segunda mitad del siglo I a.C., documenta la existencia de una servidumbre de paso (servitus viae), de catorce pies de ancho, en beneficio de la Societas Sisaponensis, que iba desde el lugar de colocación del cipo, en el suburbio septentrional de la ciudad, hasta los montes donde dicha compañía tenía arrendadas explotaciones mineras, quizás en la vecina Sierra de Córdoba. ${ }^{56}$ Asimismo los trabajos efectuados en las vías que conectaban Colonia Patricia con Emerita y Sisapo a través del Mons Marianus, buscarían facilitar el transporte del mineral hasta la capital y su embarcadero fluvial. ${ }^{57}$

Porque la otra gran arteria mercantil fue el río Guadalquivir. En época de Augusto era navegable desde Corduba para naves de poco calado, que bajaban hacia Hispalis y Gades ${ }^{58}$ Roma envió un procurator ad ripam Baetis específicamente dedicado a cuidar de su navegabilidad, pues dicha vía era muy importante para la annona de Roma, creada por Augusto, y el aprovisionamiento de otras partes del Imperio. ${ }^{59}$ Por ello la etapa de gran prosperidad material y aumento de las exportaciones que Estrabón documenta para la Bética coincide con la ampliación del pomoerium de Corduba hasta la orilla del río. La ciudad necesitó mejorar sus infraestructuras portuarias, vecinas al nuevo puente de piedra construido bajo Augusto, para dar salida a la producción agrícola y minera. Alguna información tenemos sobre una gran plaza porticada, unida por escalinatas con el embarcadero, que estaba conectada con el citado puente y la Via Augusta a través de una puerta monumental, y con el casco urbano por el cardo maximus. En esa zona a lo largo de la ribera del río se ubicarían las oficinas fiscales y comerciales, las sedes de corporaciones y transportistas fluviales documentadas epigráficamente (scapharii, lyntrarii, portonarii), tabernae, instalaciones industriales, almacenes (horrea), etc. ${ }^{60}$

52 Vid. Sillières 1990, 453-466, y MelChor 1995, 115-122, para su posible trazado.

53 A partir de Augusto, con los trabajos de acondicionamiento de su cauce, el Baetis sería la principal salida del mineral de Sierra Morena central y oriental (Melchor 1993, 2008-2009). En Hispalis el producto se transfería de las barcazas fluviales a barcos mayores. Vid. CHIC 1990, 65-81.

54 Sobre su trazado y etapas Sillières 1990, 496-500; MelChOR 1995, 151-154.

55 Plin., $N H 33.118$.

56 CIL II²/7, 699a; Ventura 1993b; Melchor 1995, 162-165.

57 Sillières 1990, 758-760. Vid. también MelChOR 1993, 2008-2009; Chic 1997, 153-159.

58 Estrab., 3.2.3. Sobre su acondicionamiento y tráfico comercial: CHIC 1990, 21-42, 81-87.

59 Vid. Dardaine-Pavis d'Escurac 1983.

60 Sobre esas instalaciones portuarias: LEÓN 2010. 


\section{Sociedad y actividades económicas}

Corduba pudo alcanzar los treinta mil habitantes en época de Augusto, llegando a ser entonces la ciudad más poblada de la Bética. Esos cálculos se basan en la extensión de su oppidum, unas setenta hectáreas; el abundante caudal del Aqua Augusta, unos veinte mil metros cúbicos de agua al día; y la capacidad del teatro, también erigido por aquel tiempo, que pudo albergar entre diez y quince mil espectadores, el mayor de Hispania. ${ }^{61}$ Esa población también había cambiado mucho cualitativamente respecto a la amalgama étnica asentada dos siglos antes por Claudio Marcelo. Ya en la etapa cesariana la integración cultural entre los dos grupos de habitantes, el romano y el indígena, tras muchos decenios de convivencia, debía de ser casi total. Pero una buena parte de sus moradores desapareció durante las guerras civiles, aunque dos deductiones de veteranos contribuyeron a su recuperación demográfica.

En la generación de cordobeses que conoció aquellos tiempos difíciles y la transición del Segundo Triunvirato, encontramos nombres propios, que constituyen elocuente testimonio de las oportunidades de promoción social que irían surgiendo con el nuevo régimen imperial. ${ }^{62} \mathrm{El}$ caso más significativo fue el clan de los Anneos, ascendido al orden senatorial. La familia sobrevivió en los turbulentos años del final de la República, salvaguardó sus intereses materiales, y estableció provechosas relaciones dentro de la provincia y en Roma. Annaeus Seneca, padre del famoso filósofo, pudo trasladarse a la Urbs, donde su gens consiguió labrarse un destacado futuro político. Amigo suyo fue Clodius Turrinus, cuyo abuelo había recibido a César en su mansión cordobesa. ${ }^{63}$ Y también Marcus Porcius Latro, prestigioso abogado en Roma y maestro de Ovidio. Séneca cuenta una anécdota que le sucedió un día, posiblemente del 5 a.C., en que intervenía en Corduba en un juicio que tuvo que trasladarse al interior de la basílica. ${ }^{64}$ Discípulo suyo fue Lucius Acilius Lucanus, abuelo materno del poeta Lucano.

También Colonia Patricia parece ser la ciudad de la Bética con mayor número de individuos de rango ecuestre en época imperial, ocupando puestos civiles y militares en la nueva burocracia creada por Augusto. ${ }^{65}$ Como tales ascensos eran por nombramiento del emperador, debemos suponer que sus recomendaciones, y también las de los gobernadores que pasaban un tiempo en Corduba, influirían en tales promociones. Caso singular, cuyo perfil debió de repetirse en otros coetáneos, es el de T. Mercello Persinus Marius, sin duda personaje importante en la Corduba augustea. En primer lugar hay que destacar sus entronques familiares y su riqueza. Estaba emparentado con el italicense L. Mercello, que participó en la conjura contra Casio Longino en el 48 a.C., quienes la

61 Ventura 2009, 378 y n. 16.

62 Esos nuevos horizontes se abrieron también para otras familias notables de la provincia, al convertirse Colonia Patricia en polo de atracción donde asentarse y establecer provechosos contactos, que les facilitaran elevarse socialmente y progresar en sus carreras públicas (MELCHOR 2006).

63 Sen., Contr. X, praef. 14.

64 Basílica ya documentada en época cesariana (Bell.Alex. 52-53), que estaría situada en el foro colonial, quizás en su flanco sur, y que sería restaurada en época tardo-republicana o augustea. Vid. sobre este asunto VENTURA 2009, 391-395.

65 Vid. Caballos 1995, 1998. 
lideraron eran gente destacada en la provincia. ${ }^{66}$ Pero también estaba vinculado a los Persii, que tenían intereses en la zona minera de Epora y en la banca. E igualmente con los Marii, propietarios de minas de cobre y oro de Sierra Morena, cuyo principal exponente fue el famoso Sexto Mario. ${ }^{67} \mathrm{~A}$ su vez algunos Marii, libertos de los Persini, están constatados en Corduba y Epora. ${ }^{68} \mathrm{O}$ sea tenemos familias que hicieron fortuna con la minería, sin duda el sector económico más próspero en la Corduba tardo-republicana.

En segundo lugar hay que destacar su carrera política. Para empezar a nivel local, es uno de los primeros magistrados coloniales que conocemos, ejerciendo edilidad y duunvirato. Pero luego llegó a ser procurator Augusti, lo que confirma sus buenas relaciones con el régimen imperial. ${ }^{69} \mathrm{La}$ basa cilíndrica por la que conocemos sus funciones locales recoge igualmente el homenaje que le tributaron los coloni et incolae. Y estuvo ubicada en la zona del teatro, erigido en tiempos de Augusto. Ello nos lleva a otro hecho destacable, el evergetismo de los Mercellones-Persini, reflejo de su riqueza. Del teatro proceden asimismo marcas de cantero grabadas en las cornisas con las siglas $M P$, lo que sugiere que dicha gens pudo contribuir a la ornamentación del edificio, o bien ser propietaria de las explotaciones que suministraron los materiales de construcción. ${ }^{70}$

Otro elocuente ejemplo de aquella élite cordobesa sintonizada ideológicamente con el nuevo sistema político, con ansias de promoción personal, pero igualmente sensibilizada con el progreso material de su ciudad, lo tenemos en L. Manlius Bocchus, cuya tribu Galeria le conecta con la población de la segunda deductio colonial. ${ }^{71}$ Después de servir en el ejército como tribunus militum, función que pudo ejercer en la legio XVI Gallica en la que se licenciaría, volvió a su lugar de origen para implicarse en la palestra política municipal, llegando a ser duunviro y praefectus iure dicundo a fines de Augusto o ya en época de Tiberio. ${ }^{72}$ En el mismo sentido debemos mencionar a L. Cornelius, adscrito a la tribu Sergia, por tanto posible descendiente de colonos asentados en la deductio cesariana. A fines del reinado de Augusto, o ya en el de Tiberio, desempeñó la edilidad y financió la construcción de varias fuentes públicas, que sin duda mejoraron el servicio prestado por la nueva Aqua Augusta. ${ }^{73}$

La riqueza y liberalidades acreditadas en aquellas gentes de época augustea reflejan claramente que la fundación de Marcelo se había convertido en potente centro económico del sur de Hispania. El sector que más había progresado en tiempos republicanos, había sido sin duda la minería. ${ }^{74}$ Son numerosas y muy elocuentes las referencias de los autores clásicos a la riqueza metalífera y alta rentabilidad de sus minas. Estrabón, por ejemplo, destaca sus yacimientos de cobre, explotados desde el siglo II

66 Bell.Alex. 52-55.

67 Sobre este personaje, su gens y conexiones familiares: Ventura 1999, 71 ss, y 2009, 388 ss.

68 CIL II ${ }^{2} / 7,153,544$.

69 CIL II'/7, 311; HEp. 2, 1990, 345.

70 Cfr. Ventura 1999, 68 ss.

71 CIL II ${ }^{2} / 7,284$.

72 Cfr. Ventura 2009, 385-388.

73 CIL II2/7, 217-218: lacus siliceos effigies aheneas de sua pecunia fecit. Cfr. Ventura 2009, 389.

74 Vid. Domergue 1990, esp. 179-196 y 229-277; García Romero 2002. 
a.C. ${ }^{75}$ La producción cuprífera fue especialmente importante en la zona serrana cordobesa, hasta el punto de que llegó a reconocerse como aes Cordubense al cobre procedente del Mons Marianus, a lo que también puede hacer referencia el apelativo de aes Marianum. ${ }^{76}$ En el conventus Cordubensis se han localizado arqueológicamente y catalogado numerosas minas, fundiciones, lavaderos, poblados, etc. ${ }^{77}$

A la abundancia en cobre hay que sumar los importantes recursos en plomo-plata y cinabrio. Desde época republicana buena parte del plomo argentífero consumido en el Imperio romano procedía de las minas cordobesas, los principales filones radicaban en las cuencas alta y baja del Guadiato y la zona granítica de los Pedroches. ${ }^{78}$ En cuanto al cinabrio o minium explotado en la comarca de Sisapo, era muy apreciado especialmente para elaborar un colorante, el bermellón, y para purificar el oro y la plata por medio del procedimiento de amalgama, que los romanos seguramente ya conocieron. ${ }^{79}$

Las minas eran propiedad estatal, siendo arrendada su explotación mediante locatio censoria bien a societates publicanorum, o a particulares solos o agrupados en societates. Entre ellas la mejor conocida es la citada societas Sisaponensis, plenamente activa en Corduba en época de Augusto, allí tendría sus oficinas. ${ }^{80}$ Muestra de su influencia es la mencionada servitus viae, cuyo disfrute debió de obtener de las instancias oficiales en la segunda mitad del siglo I a.C., asumiendo su mantenimiento y otras infraestructuras asociadas. Sin embargo desde época de Augusto aumentó el control estatal sobre los cotos mineros, que fueron pasando gradualmente al fiscus, siendo gestionados a través de procuratores. ${ }^{81}$ Suetonio recuerda que Tiberio arrebató a muchas ciudades y particulares el derecho a explotar minas. ${ }^{82}$

No tenemos ciertamente mucha información para identificar nominalmente a quienes pudieron hacer fortuna con los negocios mineros. El ejemplo de referencia es el citado Sexto Mario, cuyas minas fueron confiscadas por Tiberio en el 33 d.C. ${ }^{83}$ Se ha sugerido también que el ya citado T. Mercello Persinus Marius pudo hacerse rico con la explotación de minas y canteras, fortuna que pudo ostentar a través de sus actos evergéticos. Su onomástica, como vimos, podría conectarle con familias de la capital provincial y de Epora, como los Marii y los Persii, que también tenían intereses en la minería del Mons Marianus. ${ }^{84}$ Pero otro importante clan cordobés vinculado al sector pudieron ser los preclaros Annaei, su riqueza debía venir de antaño y al pare-

75 Estrab., 3.2.7 y 2.9. Vid. García Romero 2002, 75-78, 118-123. Y Domergue 1990, 3-14, para las referencias de los autores clásicos sobre la riqueza minera de Hispania.

76 Plin., NH 34.4: aes Marianum quod et Cordubense dicitur.

77 Domergue 1987, 86-180; García Romero 2002, 106-115, 130-209.

78 Estrab., 3.2.8; Plin., NH 34.164-165. Vid. GARCía Romero 2002, 88 ss.

79 Estrab., 6.6.12; Plin., NH 33.40 y 118-122. Vid. CHIC 1991.

80 En ellas pudieron trabajar los libertos Argentarii pertenecientes a dicha societas, mencionados en un epígrafe de Córdoba $\left(C I L \mathrm{II}^{2} / 7,415 \mathrm{a}\right)$.

81 Cfr. Domergue 1990, 234-240, 279-301.

82 Suet., Tib. 49

83 Tac., Ann. 6.19.1. Un esclavo suyo, de nombre Corinthius, es mencionado en un epígrafe funerario de Corduba $\left(C I L \mathrm{II}^{2} / 7,441\right)$.

84 Cfr. Ventura 1999, 71 ss; Melchor 2006, 254 ss, nn. 13-15. El topónimo mons Marianus y el aes Marianum quod cordubense (Plin., NH 34.4) deben referirse a tales explotaciones mineras. 
cer lograron salvaguardarla en los tiempos difíciles. Supieron igualmente establecer interesantes y provechosas relaciones familiares con gentes de buena posición social y económica, como los Aemilii y los Argentarii, así como con los Helvii de Urgavo, familia a la que pertenecían Helvia la madre del filósofo Séneca, y su abuelo materno, M. Helvius Novatus, que fue duunviro en dicha localidad. ${ }^{85}$

Otra interesante conexión se estableció a través del tercer hijo de Séneca padre, el ecuestre M. Annaeus Mela, casado con Acilia, de familia cordobesa. Tuvieron un hijo, el poeta M. Annaeus Lucanus, que matrimonió a su vez con Argentaria Polla. ${ }^{86}$ La gens Argentaria, que pudo alcanzar también el rango ecuestre, tenía intereses en las minas de plomo argentífero y cinabrio a través de la societas Sisaponensis. Una empresa que, como vimos, disponía de personal servil con el nomen Argentarius, alusivo a la actividad minera, y que extendió sus tentáculos al mundo financiero en Cor$d u b a$, pero igualmente en la propia Roma, a través de sus libertos. ${ }^{87}$ Una proyección económica que los Annaei también asumieron, basta recordar que el propio Séneca, que poseía una gran fortuna, la forjó en parte con operaciones de préstamo, que extendió no sólo a Italia, sino también a lugares lejanos de Roma, como Britania. ${ }^{88}$ Con más razón sus intereses pecuniarios pudieron abarcar su tierra de origen. Y es que en la antigua fundación de Claudio Marcelo, ya en los albores del Imperio, debía de moverse mucho dinero generado por la minería y, consecuentemente, por el comercio de metales. Pero también otros hechos tuvieron sin duda repercusión económica. Por ejemplo el funcionamiento de una ceca imperial organizada por Agripa en el 19 a.C., para pagos relacionados con las guerras cántabras y la instalación de militares veteranos asentados en la Hispania Ulterior. ${ }^{89}$ La irrupción de este numerario, acuñado aprovechando los recursos metalíferos de Sierra Morena, debió de suponer un importante movimiento de dinero (se emitieron denarios y aureos), que en buena parte pasaría a la banca privada en operaciones de depósito y préstamo que beneficiarían al gremio de los argentarii, y más concretamente a la gens Argentaria cordobesa. ${ }^{90}$

Sin alcanzar la importancia del sector minero, otros vértices económicos pudieron generar riqueza en Corduba desde fines de época republicana. En primer lugar la agricultura, a cuyo desarrollo en la etapa alto-imperial pudieron contribuir capitales transferidos del negocio minero. ${ }^{91}$ Su alto nivel de producción es confirmado por campos de silos localizados en la vecina campiña con gran capacidad de almacenamiento. ${ }^{92}$ El comercio frumentario debió de incrementarse notablemente bajo Augusto, como confirma Estrabón, ${ }^{93}$ y debió canalizarse a través del puerto fluvial. También la crea-

85 Vid. Caballos 1990, 53-56 sobre el clan senatorial de los Annaei. Para sus conexiones familiares y amistades: Ventura 1999, 70 ss, y 2009, 390-395; Ventura - Stylow 2006.

86 Cfr. Dardaine 1983; Ventura - Stylow 2006, 277.

87 Cfr. CIL II'/7, 415, 415a.

88 Cfr. Dio Cas., 62.2.1; Tac., Ann. 13.42.4.

89 Vid. García y Bellido 2006, 260-264.

90 Uno de los escasos coactores argentarii documentados en Hispania actuó precisamente en Colonia Patricia en el siglo I d.C. (CIL II²/7, 342).

91 Como ya sugirió Domergue 1972.

92 Vid. LACORT 1985.

93 Estrab., 3.2.6. Cfr. también Justin., 44.1.5. 
ción del servicio imperial de la annona, cuyo primer praefectus fue precisamente un oriundo de la Bética, el gaditano C. Turranius Gracilis, pudo ser otro factor que favoreciera las exportaciones. ${ }^{94}$ En cuanto al negocio del aceite, la llegada de inmigrantes romano-itálicos instalados en las nuevas colonias fundadas en el valle del Guadalquivir entre César y Augusto, y la situación de estabilidad en la provincia y seguridad general en el Mediterráneo, debieron de favorecer el desarrollo de este sector económico, que no muchos decenios después adquiriría enorme pujanza y rentabilidad, siendo la zona ribereña del Baetis entre Córdoba y Sevilla, y el valle bajo del Singilis (Genil), las principales comarcas productoras. ${ }^{95}$

También hay que valorar la importancia que pudo tener Colonia Patricia en aquel tiempo por su ganadería e industria textil. Su territorium se extendía hacia el interior del Mons Marianus, abarcando áreas de silvae y pascua, que en parte pudieron ser de titularidad municipal, aunque abiertas al uso de particulares a cambio del pago de un vectigal. ${ }^{96}$ Disponer de tales pascua era importante para el desarrollo del sector ganadero, que en el caso del sur de Hispania las fuentes destacan por su abundancia y variedad, y que pudo ofrecer atractivas ganancias en ciudades con amplias áreas serranas. ${ }^{97} \mathrm{En}$ cuanto a la textrina, en tiempos de Augusto la Turdetania exportaba muchos y apreciados tejidos de lana, y poco después Columela señala que en los alrededores de Corduba se criaba una excelente raza de carneros de lana oscura y rojiza. Esas lanas cordobesas, y en general los tejidos de la Bética, fueron entonces muy apreciados en Roma..$^{98}$ Ello refleja un aprovechamiento ganadero con proyección industrial, que pudo constituir un atractivo negocio para algunas familias pudientes de la ciudad, ya que dicha industria requería abundante materia prima para que su producción y comercialización resultaran rentables. ${ }^{99}$

La industria textil requería otra actividad subsidiaria, la elaboración de tintes. Además de la cotizada púrpura, había otras opciones. Por ejemplo un colorante escarlata muy utilizado por ser más barato, la cochinilla, de la que Estrabón destacaba la importante producción y exportación desde Turdetania en su tiempo. Se extraía de las secreciones de un insecto, el quermes (coccum), parásito de especies arbóreas abundantes entonces en Hispania, y concretamente en Sierra Morena, así el coscojo. ${ }^{100}$ Esas mismas zonas de entresierras del territorium cordobés, cubiertas de superficies arbustivas, serían también aptas para la apicultura, sin duda otro interesante negocio

94 Vid. PAVIS D'EsCurac 1976, 317-319.

95 Vid. al respecto SÁEz 1987; ChIC 1985, 1988; Remesal 1977-1978, 1986; Leal 2005.

96 Cfr. Hyg., De limit.const. 198 y 202 L.; Frontin., De contr.agr. p. 54. Estrabón (3.2.3) también describe la llanura ubicada al sur del Baetis como una zona fértil, cubierta de grandes arboledas y buena para pastos.

97 Estrab., 3.2.4 y 6. Vid. Mela, Chor. 2.86.

98 Cfr. Estrab., 3.2.6; Col., r.r. 7.2.4-5; Plin., NH 8.191; Mart., Ep. 12.63.3; 1.96.4-5; 5.37.7; 8.28.5-6; 9.61.3-4; 12.98.2; 12.65 .5 , etc.

99 El tío del agrónomo gaditano Columela, que poseía áreas de pastos en la zona de Ceret, se dedicaba a cruzar ovejas autóctonas con otras importadas del norte de África, seguramente para mejorar la calidad de sus lanas con vistas a su comercialización (Col., r.r. 7.2.4-5).

100 Cfr. Estrab., 3.2.6. Sobre dicha actividad económica: Alfaro 1984, 203 ss; Fernández Uriel 2010. 
en manos de personas con recursos económicos dispuestas a invertir en ello, pues su comercialización sólo resultaba rentable si el producto se obtenía en cantidad. ${ }^{101}$

Debemos valorar también la rentabilidad que pudieron tener para la economía local las extensiones de silvae del Mons Marianus. La ciudad pudo contar con dotaciones forestales de titularidad pública, cuya explotación también podía arrendarse a conductores privados pagando a cambio vectigalia. ${ }^{102}$ Sabemos que cuando se fundó la colonia cesariana de Urso se le asignaron bienes comunales consistentes en agri y silvae. ${ }^{103} \mathrm{El}$ aprovechamiento más rentable de las áreas boscosas sería la producción y comercio de madera, muy demandada para multitud de usos: combustible para viviendas, termas y hornos cerámicos y metalúrgicos, numerosos tanto en el valle del Baetis como en las comarcas mineras. Asimismo se necesitaba mucha madera para la construcción pública y privada, importantes por el desarrollo urbanístico y monumental de muchas ciudades béticas desde época de Augusto. Y para la construcción naval, el progreso del comercio fluvial y marítimo en el valle del Baetis por aquel tiempo incrementaría la demanda. ${ }^{104}$

Por supuesto las comarcas metalíferas consumían también mucha madera, en el Mons Marianus fundamentalmente de encina (quercus ilex), también pudieron aprovecharse el alcornoque (quercus suber) y la coscoja (quercus coccifera). ${ }^{105}$ En los poblados mineros era imprescindible como combustible doméstico, pero sobre todo para el entibado de pozos y galerías, traviesas, puntales, tirantas, piezas de norias, tornos, canalizaciones, cuñas, mazos, armaduras de cubos de esparto, palas, escaleras, etc. También algunas piezas del tornillo de Arquímedes (cochlea), máquina utilizada para extraer agua de las galerías, se hacían con madera de encina, como se ha documentado arqueológicamente en algunas minas cordobesas. ${ }^{106} \mathrm{El}$ reglamento de Vipasca muestra lo importante que era garantizar el abastecimiento de dicha materia prima en las zonas mineras, donde su consumo sería alto. ${ }^{107}$

Ya desde tiempos de Augusto Colonia Patricia debió de ser un destacado polo de atracción laboral tanto para la población de su entorno, como para gentes procedentes de otras provincias o incluso de fuera de Hispania. La Arqueología ha ido mostrando cómo la ciudad se fue rodeando de un cinturón de suburbia, que acogieron diversas instalaciones industriales. ${ }^{108}$ Por ejemplo talleres cerámicos, ya que la demanda de

101 Autores como Estrabón y Justino señalan la amplia producción de miel en la Bética destinada a la exportación (Estrab., 3.2.6; Justin., 44.1.5). Vid. al respecto RodríGuez NeILA 1994 y FernáNDEZ URIEL 2011. Lo mismo sucedería en el caso de otro aprovechamiento subsidiario, la cera, que Estrabón incluye también entre las principales exportaciones de Turdetania en su tiempo.

102 En Urso las locationes de propiedades públicas se efectuaban por períodos quinquenales prorrogables, proporcionando ingresos al erario colonial (LCGI, 82, 96). Sobre el tema: SÁEz 1997.

103 LCGI, 82. Los gromáticos señalan cómo en las fundaciones coloniales el ager no distribuido entre particulares se repartía entre subseciva (tierra que quedaba sin medir y asignar) y áreas públicas reservadas a pastos comunales (compascua) y bosques (Hygin., De lim.const. 201 L.).

104 Según Estrabón $(3.2 .4 ; 3.2 .6)$ los astilleros funcionaban en Turdetania “con madera del país”. Las vías que descendían desde el Mons Marianus facilitarían su transporte a lomos de animales hasta los astilleros de ribera. Vid. al respecto SiLLIÈRES 1990, 744-746.

105 El nombre de coccifera alude al coccum, quermes o cochinilla, que se desarrolla en estos arbustos.

106 Vid. GARCía Romero 2002 315-324.

107 Vip., I 9.10.12.

108 Vid. Murillo-Vaquerizo 2010, esp. 476-485. 
materiales de construcción debió de ser importante entonces con la ampliación del pomoerium hasta el río, la edificación de viviendas para los nuevos pobladores y el desarrollo monumental. ${ }^{109}$ Esa transformación urbana movilizaría a una variada gama de artesanos, cuya actividad se vería favorecida por la existencia de sectores pudientes de gustos refinados y alto poder adquisitivo. La arquitectura monumental y la estatuaria han dejado significativas muestras de su alto nivel, confirmando la labor de expertos sculptores y marmorarii, algunos pudieron llegar desde la propia Urbs. ${ }^{110}$ A su vez el cercano suministro de metales desde el Mons Marianus facilitaría el trabajo de los talleres metalúrgicos, algunos de los cuales debieron ubicarse en el suburbium septentrional. Para el momento que nos ocupa la epigrafía nos ilustra sobre oficios como el de brattiarius, un institor armorum, o la existencia de una societas aerariorum que contaba con su propio liberto medicus. ${ }^{111}$

\section{El renacimiento urbanístico}

Es poco lo que se conoce del urbanismo de la Corduba republicana. Estuvo fuertemente amurallada, sus baluartes pudieron resistir las incursiones lusitanas del siglo II a.C., o el primer ataque de César a fines del 46 a.C., durante la "guerra de Munda". Ese perímetro defensivo encerraba un extenso pomoerium, quizás por acoger contingentes militares asentados de forma más o menos permanente. La ciudad dispuso pronto de un forum con una basílica, mencionados en las fuentes literarias, y también se han documentado arqueológicamente algunos edificios públicos y vestigios de arquitectura doméstica. ${ }^{112}$ Pero el asalto cesariano de marzo del 45 a.C. produjo gran ruina material en todo el conjunto urbano, de la que han quedado algunas evidencias. No obstante, tras un paréntesis de postración, Corduba experimentaría un radical renacimiento en todos los órdenes. En los decenios posteriores a dicha catástrofe debió de ser objeto de amplios planes de reconstrucción, acelerados sobre todo cuando la paz se asentó en el sur de Hispania tras las guerras civiles. Tal proceso estuvo en consonancia con tres hechos decisivos ya bajo el gobierno de Augusto: su categoría de colonia civium Romanorum, la capitalidad de la provincia Bética, y ser sede de uno de sus cuatro conventus jurídicos. De hecho suele hablarse de una auténtica "refundación" de la ciudad ya como Colonia Patricia, ${ }^{113}$ patente en su nueva imagen urbanística y en la monumentalización de sus espacios cívicos, imitándose los modelos vigentes en la propia Urbs en los foros y edificios para

109 Pocos decenios antes el estatuto de la colonia Genetiva Iulia Urso confirma la actividad de las figlinae teglariae desde inicios del asentamiento, disponiendo que se ubicaran fuera del oppidum las que superaran determinadas dimensiones (LCGI, 76).

110 Vid. al respecto MÁRQUEZ 1998; LóPEZ 1998.

111 CIL II²/7, 333, 334, 337. Según Domergue 1990, 270, dicha societas aerariorum, cuya denominación quizás podría completarse como fodinarum cordubensium, pudo ser una empresa arrendataria de minas de cobre.

112 Para la evolución urbanística de la ciudad en tiempos anteriores a Augusto: STYLOW, 1990; LEÓN 1999; Murillo-VAQUERIZO 2010.

113 LeÓn 1993. Visiones globales del urbanismo de Corduba romana en: STYLow 1990; CARRILLO ET ALII 1999; VAQUERIZO-Murillo-GarRiguet 2011. 
espectáculos, ahora convertidos en espacios de propaganda política y, por tanto, de exaltación del régimen imperial. Se adoptaron los patrones decorativos entonces de moda, y se introdujeron los bellos mármoles importados de Luna, lo que sugiere el patrocinio imperial, al ser el Princeps propietario de tales canteras. ${ }^{114}$

El primer rasgo a destacar en la nueva fisonomía urbana es que el antiguo pomoerium fue ampliado, expandiéndose hasta la misma orilla del Baetis. La ciudad necesitaba ese desahogo espacial por varias razones. Debía albergar una población que, tras una etapa de recesión demográfica, se había ido recuperando con las dos deductiones de licenciados del ejército. Por añadidura el importante papel económico que Corduba había ido adquiriendo hacía necesario conectar el núcleo urbano con tan importante vía fluvial, salida para sus exportaciones agrícolas y mineras. La destrucción de la ciudad y las confiscaciones de bienes de los vencidos ordenadas por César, ${ }^{115}$ debieron de agilizar las transferencias de propiedad y la oferta de suelo para construir. Ese proceso de renovación urbanística iniciado bajo Augusto, sería completado en los decenios siguientes bajo los emperadores julio-claudios y flavios.

El pomoerium alcanzó ahora unas setenta y ocho hectáreas, y el cinturón defensivo, que tuvo nueve puertas, fue reparado y mejorado. El trazado viario de época republicana, articulado en una retícula de kardines y decumani, se perpetuó en la trama de época imperial, alcanzando el kardo maximus los veintidós metros de anchura, dimensiones propias de las grandes metrópolis. Las calles fueron pavimentadas y algunas contaron con pórticos. ${ }^{116}$ Elocuente símbolo de los nuevos tiempos que se abrían para Colonia Patricia fueron los foros, porque tuvo dos. Estaba el antiguo forum colonial de época republicana, sin duda elemento de referencia en el conjunto urbano, dando nombre al que debemos suponer principal barrio de la ciudad imperial, el vicus Forensis, documentado epigráficamente al igual que el denominado vicus Hispanus. ${ }^{117}$ Sobre el pavimento original del siglo II a.C., se ha apreciado un nivel de destrucción, que puede relacionarse con los trágicos acontecimientos acaecidos en marzo del 45 a.C. Reconstruido y ampliado tras las guerras civiles, fue ya bajo Augusto cuando experimentó una notable transformación, dentro del reordenamiento general del casco urbano en torno a sus dos principales ejes viarios, el cardo y el decumanus máximos. ${ }^{118}$

Este primer foro debió de albergar los principales edificios oficiales de la colonia, la citada basílica, sede de operaciones mercantiles, así como el comitium, la curia y el tabularium municipal, como vemos en otros foros coloniales de época republicana.

114 Vid. MÁrquez 1998, esp. 203-210.

115 Cfr. Dio Cas., 43.39.4-5.

116 Se han identificado arqueológicamente algunos kardines y decumani, que definen una retícula regular de parcelas no muy amplias, que podría relacionarse con un reparto entre veteranos de la milicia asentados en la ciudad. Son insulae de 2x1 actus, que acogieron viviendas con peristilo. Vid. CARRILlo 1999.

117 CIL II²/7, 272-273. Vid. MÁrquez 2009, 106-108.

118 Localizado en la confluencia de las calles Góngora y Cruz Conde, tenía forma rectangular y medía 130 x 65 m, estaba porticado y pavimentado con losas de caliza micrítica gris ("piedra de mina"), y acogía también dos arcos honoríficos documentados por sendas claves de cronología julio-claudia. Sobre dicho espacio foral: Garriguet 2002, 109-119; Márquez - Ventura 2005, 430-438; Márquez 2009, 174-176; Almoguera 2011. 
Aunque no debe descartarse que, al reestructurarse en época augustea, de acuerdo con la condición de colonia civium Romanorum y las nuevas instituciones de gobierno (ordo decurionum, magistraturas, etc.), se reformara el antiguo edificio del senado local (curia) o se construyera uno nuevo, a fin de ser sede de una corporación que pudo alcanzar los cien miembros. ${ }^{119}$ En su entorno se ubicarían igualmente el macellum, unas termas y varias tabernae, así como mansiones aristocráticas del vicus Forensis, de las que han quedado vestigios materiales. Asimismo se han localizado basas con inscripciones y restos de estatuas ecuestres y pedestres, togados y personajes femeninos, que testimonian un amplio programa escultórico, lo que indica que dicho espacio se fue configurando como escenario de representación de la élite local, entre la que se fue extendiendo el uso de inscripciones honoríficas para honrar a sus más preclaros miembros. ${ }^{120}$

Un detalle interesante, que acredita la importancia de este foro como centro cívico, es que se marcaron calles en su pavimento, para poder usarlo periódicamente como saepta en las votaciones de las curiae. Aunque no sabemos si ese diseño perpetuó el ya existente en la antigua colonia latina, o guarda relación con el estatus de colonia romana y el funcionamiento de las nuevas instituciones. ${ }^{121}$ La distribución de la ciudadanía en veinticuatro curiae y sus respectivas denominaciones aparecen en la nueva tabla del estatuto de la colonia Genetiva Iulia. ${ }^{122}$ En Colonia Patricia el número de curiae pudo ser treinta, como en Roma. Sus nombres pudieron honrar a la gens Iulia y sus antepasados, pero también a personajes importantes en la historia de la ciudad, como el fundador Claudio Marcelo o los deductores de las colonias cesariana y augustea. ${ }^{123}$

No mucho tiempo después, a fines del gobierno de Augusto o ya bajo Tiberio, se erigió otro forum (novum o adiectum) al sur del anterior, cuyo desarrollo monumental se prolongaría algún tiempo. ${ }^{124}$ Para su construcción debieron comprarse terrenos o usarse solares expropiados, derribándose viviendas que habrían formado parte del $\mathrm{vi}$ cus Forensis. Este foro, porticado y enlosado, fue diseñado a escala colosal, teniendo como modelo el que Augusto erigió en Roma, donde se consagró un templo a Mars Ultor. Todo el conjunto se construyó en mármol de Luna, y es posible que trabajaran arquitectos y artesanos llegados de la Urbs. Este nuevo espacio público, que testimoniaba el esplendor de la renacida Colonia Patricia, pudo acoger la sede del procónsul y las oficinas de la nueva administración provincial. Y simbolizaba la justicia que debían impartir allí los gobernadores provinciales como delegados del emperador. ${ }^{125}$

119 Pudo ser también el tamaño del ordo decurionum en la colonia Genetiva Iulia Urso. Sobre los senados municipales, su composición y funcionamiento: Rodríguez NeILA 2013. Para las curiae: SolER ET ALII 2013.

120 Sobre esta documentación arqueológica: MÁrQUEZ 1998; LóPEZ 1998; LóPEZ-GARRIGUET 2000.

121 Vid. Márquez - Ventura 2005, 431-434. Ventura 2009, 390, calcula entre ocho y diez mil los ciudadanos que tendrían derecho a participar en los comitia. Sobre estas convocatorias electorales: RoDRÍGUEZ NEILA 2008.

122 LCGI, 15.

123 Vid. MÁrquez - Ventura 2005, 43. Sobre los nombres y características de las curiae en la colonia Genetiva Iulia Urso: CABAllos 2006, 224-265.

124 Sobre este forum novum: MÁrquez - Ventura 2005, 448-455; MÁrquez 1998, 2009.

125 Según Suetonio (Aug. 29.1-2) el Princeps había concebido su nuevo foro en Roma para albergar los juicios públicos. Pero significativamente desde dicho lugar debían partir los mandatarios provinciales y su 
Con tales funciones se han relacionado los restos de una schola con asientos, que habría estado ubicada en una exedra del pórtico, similar a las que hubo en el foro de Augusto. En ese lugar pudo ejercer sus tareas judiciales el procónsul de la Bética con su consilium. ${ }^{126}$ Asimismo hay que destacar el importante programa decorativo que acogió, del que nos han llegado algunos restos arqueológicos. En él pudo imitarse, al menos parcialmente, la ornamentación escultórica del citado foro augusteo, que ensalzaba los orígenes y la gloria de Roma, como vemos también en las otras dos capitales provinciales de Hispania, Tarraco y Emerita. ${ }^{127}$

Junto a los foros hablan también del esplendor monumental de Colonia Patricia en aquellos años los edificios para espectáculos. Se fueron construyendo en el siglo I d.C. para acoger los ludi teatrales, gladiatorios y circenses, que tendrían especial relevancia en una ciudad con tan importante vida social y económica. El teatro, erigido probablemente entre el 15 a.C. y el 5 d.C., fue el mayor de Hispania, con $125 \mathrm{~m}$ de diámetro y capacidad entre diez y quince mil espectadores, equiparable a los de la capital del Imperio. ${ }^{128}$ En su entorno hubo plazas en terraza conectadas por escalinatas, para salvar el desnivel del terreno y permitir una cómoda evacuación del público. Sus dimensiones y decoración indican que quienes lo diseñaron se inspiraron en el teatro de Marcelo en Roma. Pudo ser inaugurado representándose alguna obra del comediógrafo cordobés Statorius Victor ${ }^{129}$ y se convirtió en todo un símbolo edilicio de la nueva expansión espacial de la ciudad.

Dada la vinculación sentimental de Augusto y su familia hacia Colonia Patricia, demostrada por diversos hechos ya expuestos, es posible que fuera erigido con apoyo financiero imperial, algo sí confirmado para los teatros de otras dos capitales provinciales de Hispania, Emerita (Agripa) y Carthago Nova (Gayo y Lucio Césares). Tampoco cabe descartar que fuese Marcelo, sobrino y yerno del Princeps, quien se implicara en su construcción, dado su parentesco con Claudio Marcelo, el fundador de la ciudad. Lo que sí parece demostrado es que las familias más importantes de la aristocracia local se implicaron en la financiación de sus programas decorativos, como demostración de su fidelidad al Princeps. En ello se materializó la riqueza y liberalidad de gentes como los Mercellones Persinii, Marii, Annaei, Fanii, Numisii, etc. ${ }^{130}$

Hay que recordar ahora las infraestructuras hidráulicas con que fue dotada Colonia Patricia en época de Augusto. Las propias de una urbe en expansión, con crecientes necesidades de suministro hídrico, por haber crecido su población, por el embellecimiento de sus espacios públicos, y por la concentración de industrias en su entorno. Se construyó el Aqua Augusta, para la que se buscaron acuíferos de gran calidad en la

\footnotetext{
séquito cuando viajaban a sus destinos.

126 Vid. TORRERAS - VENTURA 2011.

127 Vid. Márquez 1998, 176-179, y 2009, 112-119; GARriguet 2002, esp. 119-122, 154-175.

128 Para su construcción, que aprovechó el desnivel del terreno, se usó piedra local, con revestimiento de mármoles importados. La imma cavea, con seis cunei y catorce filas, se adecuaba a las prescripciones de las leges Roscia y Iulia theatralis. La fachada presentaba tres arcadas superpuestas enmarcadas por los órdenes decorativos dórico, jónico y corintio. Sobre este edificio (arquitectura, ornamentación, epigrafía, etc.): VENTURA 1999, y principalmente VENTURA ET ALII 2002.

129 VENTURA 2009, 380.

130 Ventura 1999; Ventura - Stylow 2006.
} 
vecina Sierra Morena. Esta importante obra pública pudo ser financiada por Agripa, promotor de importantes proyectos hidráulicos en la Urbs, y refundador de la ciudad en el 19 a.C. ${ }^{131}$ Y surtió a una densa red de fuentes distribuida por plazas y calles, cuyo número se ha calculado en un centenar, a tenor del caudal de agua que aportaba, unos treinta mil metros cúbicos de agua al día. Algunas, que estuvieron decoradas con effigies aheneas, fueron donadas por uno de los primeros evergetas constatados en la ciudad, el ya citado $L$. Cornelius, magistrado municipal a fines del reinado de Augusto o ya en el de Tiberio. ${ }^{132} \mathrm{Y}$ en relación con esta importante infraestructura otra destacable aportación para la higiene urbana, que las calles se dotaran de una amplia red de cloacas, acorde con la gran extensión del pomoerium, lo cual requeriría explotar canteras cercanas dada la gran demanda de materiales pétreos. ${ }^{133}$

Pasemos ahora al ámbito religioso. Entre las élites locales de Colonia Patricia el deseo de imitar los patrones culturales de la Urbs se hace patente también en la religión y los usos funerarios. Por ejemplo la adopción de los más tradicionales cultos romanos, como los de Minerva, Ceres, Diana, Artemis, Apolo, etc. Al norte del teatro se abría una plaza que le daba acceso, donde pudieron existir varios santuarios consagrados a diversas divinidades, en la vecindad del cardo maximus. ${ }^{134}$ Pero donde más se hicieron patentes los nuevos vientos ideológicos y la fidelidad de las élites locales al nuevo régimen político, fue en el naciente culto imperial, factor que influyó mucho en la remodelación urbana de Corduba ${ }^{135}$ La más temprana manifestación de lealtad de los habitantes de la Bética hacia Augusto fue una estatua de oro de cien libras de peso, erigida en su honor el 2 a.C. en el foro que hizo levantar en Roma, sobre una basa marmórea cuya inscripción indica qué motivó tal reconocimiento: los beneficios recibidos y la paz instaurada en la provincia. ${ }^{136}$ Es obvio que los cordubenses tendrían un importante papel en dicho homenaje.

También en el foro colonial pudo construirse un templo consagrado al divus Augustus, que sería ornado con un conjunto escultórico referido a la dinastía julio-claudia. ${ }^{137} \mathrm{Y}$ el teatro, primer y emblemático edificio para espectáculos en la renaciente Colonia Patricia, se convirtió en escenario de culto imperial y de auto-representación de la nobilitas local. Asimismo la exposición en lugares públicos de inscripciones y retratos de emperadores o miembros de la domus Augusta iría proyectando públicamente la profunda identificación de la alta sociedad cordobesa con la ideología y propaganda

131 Se trata del llamado acueducto de Valdepuentes que, posteriormente, al construirse otros nuevos, pasaría a denominarse Aqua Vetus Augusta. Era en gran parte subterráneo, y llegaba hasta un castellum situado en la Puerta Osario, en la muralla norte. Sobre estas infraestructuras VenTURA 1993a, 1996.

132 CIL II ${ }^{2} / 7,218-219$.

133 Vid. Stylow 1990, 268 s.; Ventura 1993a, 155, para las cloacas. Sobre las canteras: PenCo ET ALII 2004.

134 Cfr. Vaquerizo - Murillo - Garriguet 2011, 25 ss.

135 Vid. GARRIGUET 1997a, 2002.

136 CIL VI, 31267 = ILS 103: quod beneficio eius et perpetua cura provincia pacata est. Se alude a una donación por parte de la Bética (quizás una effigies provinciae) a Augusto como pater patriae, siendo la primera referencia documental que tenemos a la nueva provincia.

137 Garriguet 1997b; 2002, 109-119. 
oficiales. ${ }^{138}$ En el entorno de su nueva aristocracia decurional se irían reclutando los pontifices y flamines del culto imperial. ${ }^{139}$

Pero fue el forum novum el espacio urbano de representación más vinculado ideológicamente al nuevo régimen político. La embajada enviada por la Bética al Senado en el 25 d.C., cuyo objetivo era obtener el permiso del emperador Tiberio para levantar un templo en su honor y en el de la emperatriz Livia, pudo obtener al menos su autorización para dedicar uno a Augusto divinizado en Colonia Patricia, lo que apoyaría una temprana fecha para el desarrollo del culto imperial en la Bética, unos decenios antes de lo que se suponía. ${ }^{140}$ Dicho edificio, de colosales dimensiones, era octástilo y períptero, sobre alto podio, con rica ornamentación marmórea. Se han recuperado restos de una inscripción en litterae aureae, posiblemente la dedicatoria. Su modelo parece haber sido el templo de Mars Ultor en la Urbs. ${ }^{141}$

Hay que destacar el importante programa decorativo que dicho forum novum acogió. En él pudo imitarse, al menos parcialmente, la ornamentación escultórica del foro de Augusto, que simbolizaba los orígenes y grandeza de Roma, exaltando a ilustres antepasados de la familia imperial. La gens Iulia se consideraba descendiente de Venus y Marte, hasta entroncar con los mitos de Eneas y Rómulo vinculados a la fundación de la Urbs. ${ }^{142}$ Mitos que, igualmente, fueron enaltecidos por el Princeps en el Ara Pacis. Toda esta parafernalia conmemorativa y glorificadora estaba en consonancia con aquella aurea aetas ensalzada por los grandes escritores de entonces. El heredero de César parece haber tenido interés en que dichos modelos se constituyeran en paradigmas ideológicos en los nuevos espacios forales de las más emblemáticas ciudades del Imperio. Especialmente en las colonias, imitaciones de Roma como afirmaba en el siglo II d.C. el poeta Aulo Gelio, ${ }^{143}$ y más concretamente en Hispania, con la que la familia imperial llegó a tener muchas conexiones, por ejemplo patronazgos sobre ciudades y financiación de proyectos edilicios. ${ }^{144}$ Por ello el nuevo forum cordobés, consagrado al culto de Augusto en la Bética (en esa zona se han hallado pedestales honoríficos de flámines provinciales), contaría también con un altar, en un entorno embellecido por esculturas como la colosal y thoracata de la colección Tienda, de gran calidad artística, posible representación de Eneas, fundador de Roma, huyendo de Troya. También pudo albergar una galería de summi viri, como en el foro de Augusto en Roma, e imágenes imperiales. ${ }^{145}$ Por lo que respecta al espacio foral localizado en la zona de los Altos de

138 CIL II²/7, 253 (Augusto sacrum), 254 (Tiberio). Vid. al respecto GARRIGUET 2001 y 2002, 19-40, 6163; León 2001. Muy cerca de Colonia Patricia, de la que sin embargo le diferenciaba su pasada fidelidad a César, tenemos a Ulia, beneficiada con diversos patronazgos de la casa imperial: Augusto $\left(C I L \mathrm{II}^{2} / 5,486\right)$, Agripa (CIL II $2 / 5,488)$, Lucio César $\left(C I L \mathrm{II}^{2} / 5,487\right)$ y Tiberio $\left(C I L \mathrm{II}^{2} / 5,490\right)$.

139 Sobre estas funciones religiosas: Castillo 1998; Delgado 1998; PANZRAm 2003.

140 Cfr. Garriguet 2002 145-175; Márquez-Ventura 2005, 454 ss.

141 Vid. Márquez 1998, 176-179, y 2009, 112-119; MÁrqueZ - Ventura 2005, 448-455; PeÑa-Ventura - Portillo 2011. Sobre la inscripción, que iría en el friso, y propuestas de reconstrucción: VentURA 2007.

142 La diosa Venus aparece precisamente representada en monedas acuñadas en Corduba a comienzos del siglo I a.C. (CHAVES 1977).

143 Aul. Gel., NA 16.13.8-9: coloniae, quasi effigies paruae simulacraque esse quaedam uidentur...

144 Vid. al respecto la contribución de E. Melchor ("El patrocinio de Augusto y de los herederos del Princeps sobre las comunidades cívicas hispanas”) en estas mismas actas.

145 Vid. Trillmich 1996, 185-189. 
Santa Ana, pudo haber estado funcionando ya en época tardo-augustea o tiberiana para venerar a la domus Augusta, siendo también sede de un santuario posiblemente dedicado a Diana y Apolo, divinidades protectoras del fundador del imperio. ${ }^{146}$

En el nuevo diseño urbano de Colonia Patricia se incluyeron también las áreas funerarias. ${ }^{147}$ Apenas tenemos restos de las necrópolis de época republicana, incluso la situada al sur del pomoerium pudo desaparecer cuando el perímetro urbano se amplió hasta el río. En tiempos de Augusto sus emplazamientos fueron regularizándose a lo largo de las vías de acceso a la ciudad, en vecindad con las instalaciones industriales ubicadas en el cinturón de suburbia, y las áreas de uso funerario se planificaron topográficamente. ${ }^{148}$ Pero quizás lo más destacable fue el desarrollo monumental de tales zonas, transformadas en espacios de auto-representación de la nueva élite colonial (progresivo uso del mármol, estatuas masculinas togadas y femeninas, litterae aureae en algunos epitafios). E igualmente la variedad tipológica de las tumbas (túmulos circulares, cámaras subterráneas, monumenta en forma de altar, etc.), como reflejo de las diferencias sociales. ${ }^{149}$ Asimismo se aprecia, tanto en los diseños arquitectónicos como en los ritos, la coexistencia de los modelos tradicionales itálicos que trajeron los inmigrantes foráneos, con pervivencias culturales indígenas e incluso del mundo púnico. También se fueron introduciendo en los acotados funerarios las medidas en pies romanos (in fronte pedes, in agro pedes), como se constata epigráficamente. ${ }^{150}$

Podemos destacar ahora la necrópolis ubicada junto a la puerta occidental (Puerta Gallegos), por donde el decumanus maximus se prolongaba en la calzada que iba a Hispalis por la margen derecha del Baetis. Fue un espacio de ostentación para algunas gentes importantes, por tratarse de un lugar de paso, y por tanto muy frecuentado, hacia el vicus suburbano del anfiteatro erigido algún tiempo después en aquella zona. Allí se emplazaron dos importantes mausoleos circulares coronados por túmulos. Se datan a inicios del reinado de Tiberio, pero se inspiraron en la gran tumba de Augusto en la Urbs, usándose materiales de lujo incluido el mármol. Desconocemos quiénes fueron sus propietarios, pero es evidente que debieron pertenecer a la nobilitas local, deseosa de exhibir su poder y prestigio con los mismos parámetros ideológicos y estéticos vigentes entonces entre las aristocracias de Roma e Italia. ${ }^{151}$

Finalmente quiero destacar que a época augustea corresponde el epitafio más antiguo de la Bética, el ara de Abullia Nigellia, procedente de la necrópolis septentrional. ${ }^{152} \mathrm{Su}$ rasgo más singular es que contiene la datación consular, lo que es excepcional: uno de agosto del 19 a.C. Quizás se indicó tal fecha porque era significativa para la historia de la ciudad, ya que aludía al día, mes y año en que habría tenido lugar la refundación de Corduba como Colonia Patricia, al efectuarse la segunda deductio llevada a cabo

\footnotetext{
146 Vid. MÁrquez 1998, 179-182; GARRIGUet 1999 y 2002, 122-129.

147 Sobre las necrópolis de Colonia Patricia y sus rituales funerarios: VAquerizo 2001, esp. 120-173.

148 Vid. Ruiz Osuna 2007, 127-131, y MuRILlo - Vaquerizo 2010, para esa evolución cronológica de los espacios funerarios.

149 Sobre estas cuestiones: Vaquerizo 2001, esp.174-245, y 2010, 105-142; RuIz Osuna 2007; STYLOW 2002; STYLOW - VentURA 2013.

150 CIL II $2 / 7,486$ (locus pedum XII).

151 Vid. Murillo - Carrillo 1999; Vaquerizo 2001, 216-219.

152 CIL II'/7, 397.
} 
por Agripa. Es decir su dies natalis. ${ }^{153} \mathrm{~A}$ la misma época corresponde la inscripción de Numerius Abullius Chrestus, patrono de la anterior. ${ }^{154} \mathrm{Y}$ también el epitafio de la liberta Gallia Monume, que recoge una expresión singular, ab oriente ad occidentem, para señalar el devenir de su vida desde el nacimiento hasta la muerte. ${ }^{155}$

\section{BibLIOGRAFÍA}

Alfaro, C. (1984): Tejido y cestería en la Península Ibérica. Historia de su técnica e industria desde la Prehistoria hasta la Romanización, Madrid.

Alföldy, G. (1969): Fasti Hispanienses, Wiesbaden.

Almoguera, J. M. (2011): "El foro colonial”, [en] VVAA, Córdoba, reflejo de Roma, Córdoba, 41-48.

BeltrÁn, F. (2011): “Les colonies latines d'Hispanie (II siècle av. È.): émigration italique et intégration politique", [en] N. Barrandon - F. Kirbihler (cur.), Les gouverneurs et les provinciaux sous la République romaine, Rennes, 131-144.

BÉRENGER-BADEL, A. (2003): "Le voyage des gouverneurs à l'époque impériale", [en] H. Duchesne (ed.), Voyageurs et Antiquité classique, Dijon, 73-86.

Burton, G. P.

(1975): "Proconsul, assizes and the administration of justice under the Empire", JRS 65, 92106.

(1993): "Provincial Procurators and the Public Provinces", Chiron 23, 13-28.

(2004): "The Roman imperial state, provincial governors and the public finances of provincial cities, 27 B.C.-A.D. 235", Historia 53-3, 311-342.

Caballos, A.

(1990): Los senadores hispanorromanos y la romanización de Hispania (siglos I-III), Écija.

(1995): "Los caballeros romanos originarios de la provincia Hispania Ulterior Bética. Catálogo prosopográfico", Kolaios 4, 289-343.

(1998): "Cities as the basis for supra-provincial promotion: the equites of Baetica", [en] S. Keay (ed.), The Archaeology of Early Roman Baetica, Portsmouth (RI), 123-146.

(2006): El nuevo bronce de Osuna y la política colonizadora romana, Sevilla.

CABAllos, A.- Eck, W.- Fernández, F. (1996): El senadoconsulto de Gneo Pisón padre, Sevilla.

Canto, A.

(1991): “Colonia Patricia Corduba: nuevas hipótesis sobre su fundación y nombre”, Latomus $50,846-857$.

(1997): “Algo más sobre Marcelo, Corduba y las Colonias Romanas del año 45 a.C.”, Gerión 15, 253-281.

Carrillo, J. R. (1999): "Evolución de la arquitectura doméstica en la Colonia Patricia Corduba", [en] F. García Verdugo - F. Acosta (eds.), Córdoba en la Historia: La Construcción de la Urbe, Córdoba, 75-86.

153 Cfr. Ventura 2009, 387 ss y n. 49.

$154 C I L \mathrm{II}^{2} / 7,396$.

$155 \mathrm{CIL} \mathrm{II}^{2} / 7,468$. 
Carrillo, J. R. - Hidalgo, R. - Murillo, J. F. - Ventura, A. (1999): “Córdoba. De los orígenes a la Antigüedad tardía", [en] F. García Verdugo - F. Acosta (eds.), Córdoba en la Historia: La Construcción de la Urbe, Córdoba, 37-74.

CAstillo, C.

(1994): "El nuevo juramento a Augusto encontrado en la Bética", [en] Y. Le Bohec, L'Afrique, la Gaule, la Religion à l'époque romaine. Mélanges à la mémoire de Marcel Le Glay, Bruxelles, 681-686.

(1998): "Los flamines provinciales de la Bética", REA 100/3-4, 437-460.

Chaves, F. (1977): La Córdoba hispano-romana y sus monedas, Sevilla.

Chevallier, R.

(1972): Les voies romaines, Paris.

(1988): Voyages et déplacements dans l'Empire Romain, Paris.

CHIC, G.

(1985): Epigrafia anfórica de la Bética 1, Sevilla.

(1988): Epigrafia anfórica de la Bética 2. Los rótulos pintados sobre ánforas olearias. Consideraciones sobre la "annona”, Sevilla.

(1990): La navegación por el Guadalquivir entre Córdoba y Sevilla en época romana. Écija. (1991): "Estrabón y la práctica de la amalgama en el marco de la minería sudhispánica: un texto mal interpretado", [en] C. González Román (ed.), La Bética en su problemática histórica, Granada, 7-29.

(1997): "La miel y las bestias", Habis 28, 153-166.

Cortuo, M. L. (1993): La administración territorial de la Bética romana, Córdoba.

Crogiez, S. (2002): "Le cursus publicus et la circulation des informations officielles par voie de mer", [en] J. Andreau - C. Virlouvet (eds.), L'information et la mer dans le monde antique, Roma, 55-67.

CurChin, L. (1985): “Vici and Pagi in Roman Spain”, REA 87,/3-4, 327-343.

DARDAINe, S. (1983): "La gens Argentaria en Hispania. La femme de Lucain avait-elle une origine hispanique?", $M C V 19$, 5-15.

Dardaine, S. - Pavis D’Escurac, H. (1983): “Le Baetis et son aménagement: l'apport de l'épigraphie (CIL II, 1183 et 1180)", Ktema 8, 307-315.

Delgado, J. A. (1988): Élites y organización de la religión en las provincias romanas de la Bética y las Mauritanias: sacerdotes y sacerdocios, Oxford.

Di Paola, L. (1999): Viaggi, trasporti e istituzioni. Studi sul cursus publicus, Messina.

DopIco, M. D. (1986): “Los conventus iuridici. Origen, cronología y naturaleza histórica”, Gerión 4, 265-283.

Domergue, C.

(1972): "Rapports entre la zone minière de la Sierra Morena et la plaine agricole du Guadalquivir à l'époque romaine", $M C V 8,614-622$.

(1987): Catalogue des mines et des fonderies antiques de la Péninsula Ibérique, Madrid.

(1990): Les mines de la Péninsule Ibérique dans l'Antiquité romaine, Roma.

Dupré, X. (ed.) (2004): Las capitales provinciales de Hispania. 1. Córdoba. Colonia Patricia Corduba, Roma. 
FERnÁNDEZ URIEL, P.

(2010): Púrpura: del mercado al poder, Madrid.

(2011): Dones del cielo. Abeja y miel en el Mediterráneo antiguo, Madrid.

García y Bellido, Ma P. (2006): “Corduba y Colonia Patricia: historia de dos ciudades”, [en] D. Vaquerizo - J. F. Murillo (eds.), El concepto de lo provincial en el mundo antiguo, I, Córdoba, 251-266.

GARCÍA FERNÁNDEZ, E.

(2002): “Observaciones jurídicas sobre la fundación de Corduba y la tribus Sergia”, [en] S. Crespo - A. Alonso (eds.), Scripta Antiqua in honorem A. Montenegro et J.M. Blázquez, Valladolid, 265-272.

(2014): "Estrabón (III 2, 1) y la fundación de Córdoba. Una nueva propuesta de interpretación”, [en] M. Chiabà (ed.), Hoc quoque laboris praemium. Scritti in onore di Gino Bandelli, Trieste, 173-187.

GARCía Romero, J. (2002): Minería y metalurgia en la Córdoba romana, Córdoba.

GARRIGUET, J. A.

(1997a): "El culto imperial en las tres capitales provinciales hispanas", AAC 8, 43-68.

(1997b): "Un posible edificio de culto imperial en la esquina sureste del foro colonial de Córdoba", Antiquitas 8, 73-80.

(1999): "Reflexiones en torno al denominado "foro de Altos de Santa Ana" y a los comienzos del culto dinástico en Colonia Patricia Corduba", AAC 10, 87-113.

(2001): La imagen del poder imperial en Hispania. Tipos estatuarios, Murcia.

(2002): El culto imperial en la Córdoba romana: una aproximación arqueológica, Córdoba.

GonzÁLEZ, J. (1988): “The first oath pro salute Augusti found in Baetica”, ZPE 72, 113-127.

HAENSCH, R.

(1992): “Das Statthalterarchiv”, ZSav 109, 209-317.

(1997): “Capita provinciarum”. Stadthaltersitze und Provinzialverwaltung in den Römischen Kaiserzeit, Mainz.

Jiménez, A. - CARrillo, J. R. (2011): “Corduba/Colonia Patricia: the colony that was founded twice", [en] R. J. Sweetman (ed.), Roman colonies in the first century of their foundation, Oxford, 55-74.

Jouffroy, H. (1986): La construction publique en Italie et dans l'Afrique romaine, Strasbourg.

KNAPP, R. C.

(1981): “L. Axius Naso and pro legato", Phoenix 35-2, 134-141.

(1983): Roman Córdoba, Berkeley.

LACORT, P. (1985): “Cereales en Hispania Ulterior: silos de época ibero-romana en la Campiña de Córdoba", Habis 16, 363-386.

LEAL, P. (2005): La Bética bajo Claudio. Una perspectiva económica. Écija.

LeÓn, E. (2010): “Portus Cordubensis", AnAAC 2, 45-72.

LEÓN, P.

(1993): "Hacia una nueva visión de la Córdoba romana", [en] P. León (ed.), Colonia Patricia Corduba. Una reflexión arqueológica, Córdoba.

(1999): "Itinerario de monumentalización y cambio de imagen en Colonia Patricia (Córdoba)", AEArq 72, 39-56.

(2001): Retratos romanos de la Bética, Sevilla. 
LóPEz, I. M. (1998): Estatuas masculinas togadas y estatuas femeninas vestidas de colecciones cordobesas, Córdoba.

López, I. M. - GARRIGUET, J. A. (2000): "La decoración escultórica del foro colonial de Córdoba", [en] P. León-T. Nogales (eds.), Actas de la III reunión sobre escultura romana en Hispania, Madrid, 47-80.

Marshall, A. J. (1966): “Governors on the move”, Phoenix 20, 231-246.

MÁRQUEZ, C.

(1998): La decoración arquitectónica de Colonia Patricia Corduba. Una aproximación a la arquitectura y urbanismo de la Córdoba romana, Córdoba.

(2009): "Transformaciones en los foros de Colonia Patricia", [en] J. M. Noguera (ed.), Fora Hispaniae. Paisaje urbano, arquitectura, programa decorativo y culto imperial en las ciudades hispanorromanas, Murcia, 105-121.

MÁrquez, C. - Ventura, A. (2005): “Corduba tras las Guerras Civiles”, [en] E.Melchor - J. Mellado - J. F. Rodríguez Neila (eds.), Julio César y Corduba. Tiempo y espacio en la campaña de Munda (49-45 a.C.), Córdoba, 429-466.

MelCHOR, E.

(1993): "Vías romanas y explotación de los recursos mineros de la zona norte del Conventus Cordubensis", $A A C$ 4, 63-89.

(1995): Vías romanas de la provincia de Córdoba, Córdoba.

(2004): "El territorio", [en] X. Dupré (ed.), Las capitales provinciales de Hispania. 1. Córdoba. Colonia Patricia Corduba, Roma, 105-117.

(2006): “Corduba, caput provinciae y foco de atracción para las élites locales de la Hispania Ulterior Baetica", Gerión 24/1, 251-279.

(2008-2009): "El Baetis y la organización viaria del Sur Peninsular: la interconexión de las redes de transporte fluvial y terrestre en la Bética romana", Anas 21-22, 163-191.

Muñiz, J. (1998): Cicerón y Cilicia. Diario de un gobernador romano del siglo I a. de C., Huelva.

Murillo, J. F. - CARrillo, J. R. (1999): “Aspectos de la monumentalización de las necrópolis de Colonia Patricia. El monumento funerario de Puerta de Gallegos”, [en] J. González (ed.), Ciudades privilegiadas en el Occidente romano, Sevilla, 365-378.

Murillo, J. F. - VAquerizo, D. (2010): “Ciudad y Suburbia en Corduba. Una visión diacrónica”, [en] D. Vaquerizo (ed.), Las áreas suburbanas en la ciudad histórica. Topografía, usos, función, Córdoba, 455-522.

NAVARRo, F. J.

(2004): "El proconsulado de la Bética en el cursus honorum senatorial", Gerión 22/1, 379402.

(2007): "Los legados del procónsul de la Bética durante el Imperio Romano", [en] Acta XII Congr. Int. Epigraphiae Graecae et Latinae (Barcelona, 2002), Barcelona, 993-998.

OJEDA, J. M. (1993): El servicio administrativo imperial ecuestre en la Hispania romana durante el Alto Imperio I. Prosopografia, Sevilla.

PANZRAm, S. (2003): "Los flamines provinciae de la Baetica: autorrepresentación y culto imperial", AEArq 76, 121-130.

PAVIS D'EsCuRAC, H. (1976): La préfecture de l'annone service administratif impérial d'Auguste à Constantin, Roma. 
Penco, F. - Moreno, M. - Gutiérrez, M. I. (2004): “Dos canteras romanas en Colonia Patricia Corduba: Peñatejada y Santa Ana de la Albaida", $A A C$ 15, 229-248.

Peña, A. - Ventura, A. - Portillo, A. (2011): "El templo consagrado a Divo Augusto y su temenos (forum novum)", [en] VVAA, Córdoba, reflejo de Roma, Córdoba, 59-67.

RAMIERI, A. M. (1996): I servizi pubblici, Roma.

REMESAL, J.

(1977-1978): "La economía oleícola bética: nuevas formas de análisis”, AEArq 50-51, 87142.

(1986): La “annona militaris" y la exportación de aceite bético a Germania, Madrid.

Rodríguez NeILA, J. F.

(1988): Historia de Córdoba. Del amanecer prehistórico al ocaso visigodo, Córdoba.

(1992): "Corduba", Dialoghi di Archeologia 10-1/2, $3^{a}$ ser.,177-194.

(1994): "El epígrafe CIL, II 2242 -Corduba- y las locationes de propiedades públicas municipales", [en] C. González Román (ed.), La sociedad de la Bética. Contribuciones para su estudio, Granada, 425-460.

(2005): “Corduba entre cesarianos y pompeyanos durante la guerra civil”, [en] E. Melchor - J. Mellado - J. F. Rodríguez Neila (eds.), Julio César y Corduba. Tiempo y espacio en la campaña de Munda (49-45 a.C.), Córdoba, 311-360.

(2008): "Los comitia municipales y la experiencia institucional romana", [en] C. Berrendonner - M. Cébeillac-Gervasoni - L. Lamoine (eds.), Le quotidien municipal dans l'Occident romain, Clermont-Ferrand, 301-315.

(2009): "Corduba romana, capital de la provincia Hispania Ulterior Baetica", [en] J. M. Escobar - A. López Ontiveros - J. F. Rodríguez Neila (eds.), La ciudad de Córdoba: origen, consolidación e imagen, Córdoba, 23-82.

(2013): "Las sesiones de trabajo de los senados municipales", [en] E. Melchor - A. D. Pérez Zurita - J. F. Rodríguez Neila (eds.), Senados municipales y decuriones en el Occidente romano, Sevilla-Córdoba, 163-213.

Rodríguez SÁnchez, M. C. (2008): "El Ager Cordubensis. Una aproximación a la delimitación del territorio de Colonia Patricia Corduba", AnAAC 1, 45-66.

Ruiz OsunA, A. B. (2007): La monumentalización de los espacios funerarios en Colonia Patricia Corduba (ss.I a.C.-II d.C.), Córdoba.

SÁEZ, P.

(1987): Agricultura romana de la Bética.I, Sevilla.

(1997): “Las tierras públicas en la Lex Ursonensis", Stud.Hist. Ha Antig. 15, 137-152.

SÁnchez-Ostiz, A. (1999): La Tabula Siarensis, Pamplona.

SANCHO, L. (1978): "Los conventus iuridici en la Hispania romana”, Caesaraugusta 45-46, 171194.

SAQUeTE, J. C. (2006): "El gobernador provincial de Lusitania y sus actividades: viajes, calzadas, conventus y relaciones sociales", [en] J. F. Rodríguez Neila - E. Melchor (eds.), Poder central y autonomía municipal. La proyección pública de las élites romanas de Occidente, Córdoba, 81-111.

Sillières, P. (1990): Les voies de communication de l'Hispanie meridionale, Paris.

Soler, B. ET ALII (eds.) (2013): Las sedes de los “ordines decurionum” en Hispania. Análisis arquitectónico y modelo tipológico, Mérida. 
STYLOW, A. U.

(1990): “Apuntes sobre el urbanismo de la Corduba romana”, [en] W. Trillmich - P. Zanker (eds.), Stadtbild und Ideologie. Die Monumentalisierung hispanische Städte zwischen Republik und Kaiserzeit, München, 259-282.

(1995): “Apuntes sobre las tribus romanas en Hispania", Veleia 12, 105-123.

(1996): "De Corduba a Colonia Patricia. La fundación de la Córdoba romana", [en] P. León (ed.), Colonia Patricia Corduba. Una reflexión arqueológica, Sevilla, 77-95.

(2002): "La epigrafía funeraria en la Bética", [en] D. Vaquerizo (ed.), Espacios y usos funerarios en el Occidente romano, Córdoba, 353-368.

Stylow, A. U. - Ventura, A. (2013): "Las inscripciones con litterae aureae en la Hispania Ulterior (Baetica et Lusitania): aspectos técnicos", [en] J. López Vilar (ed.), Actes $1^{\text {er }}$ Congrés Internacional d'Arqueologia i Món Antic, Tarragona, 301-339.

SzRAmkiewicz, R. (1975-1976): Les gouverneurs de province à l'époque augustéenne. Contribution à l'histoire administrative du Principat, Paris.

TARPIN, M. (2002): "Vici” et "pagi” dans l'Occident romain, Roma.

Torreras, S.- Ventura, A. (2011): "Una exedra con schola en Colonia Patricia”, [en] VVAA, Córdoba, reflejo de Roma, Córdoba, 68-77.

Trillmich, W. (1996): “Los tres foros de Augusta Emerita y el caso de Corduba", [en] P. León (ed.), Colonia Patricia Corduba. Una reflexión arqueológica, Sevilla, 175-195.

VAQuerizo, D. (2010): Necrópolis urbanas en Baetica, Tarragona.

VAQuerizo, D. (coord.), (2001): Funus Cordubensium. Costumbres funerarias en la Córdoba romana, Córdoba.

VAquerizo, D. - Murillo, J. F. - Garriguet, J. A. (2011): "Novedades de arqueología urbana en Corduba, Colonia Patricia”, [en] J. González - J. C. Saquete (eds.), Colonias de César y Augusto en la Andalucía romana, Roma, 9-46.

VENTURA, A.

(1993a): El abastecimiento de agua a la Córdoba romana, I. El acueducto de Valdepuentes, Córdoba.

(1993b): "Susum ad montes S(ocietatis) S(isaponensis): nueva inscripción tardorrepublicana de Córdoba", AAC 4, 49-61.

(1996): El abastecimiento de agua a la Córdoba romana. II. Acueductos, ciclo de distribución y urbanismo, Córdoba.

(1999): "El teatro en el contexto urbano de Colonia Patricia (Córdoba): ambiente epigráfico, evergetas y culto imperial", AEArq 72, 57-72.

(2006): "Una lastra “campana" en Córdoba: Asinius Pollio, el Auguraculum y la deductio de Colonia Patricia", [en] M. P. García y Bellido et alii (eds.), Del Imperium de Pompeyo a la auctoritas de Augusto, "Homenaje a Michael Grant", Madrid, 85-105.

(2007): "Reflexiones sobre la arquitectura y advocación del templo de la calle Morería en el forum adiectum de Colonia Patricia Corduba", [en] T. Nogales - J. González (eds.), Culto imperial: política y poder, Roma, 215-237.

(2009): "Las élites de Colonia Patricia, año 5 a.C.: un ejemplo de puesta en escena literaria y monumental", [en] H. Gimeno - P. Mateos - A. Ventura (eds.), Espacios, usos y formas de la epigrafia hispana en épocas antigua y tardoantigua. Homenaje al Dr. Armin U. Stylow, 375-395.

(2011): "Caracterización de la Córdoba romana, de sus fundaciones, fundadores y funciones", [en] VVAA, Córdoba, reflejo de Roma, Córdoba, 28-40. 
Ventura, A. - Márquez, C. - Monterroso, A. - Carmona, M. A. (eds.) (2002): El teatro romano de Córdoba, Córdoba.

VenturA, A. - Stylow, A. U. (2006): "Nuevos datos sobre los antepasados maternos de Lucano y las relaciones familiares de los Annaei cordubenses", [en] D. Vaquerizo- J. F. Murillo (eds.), El concepto de lo provincial en el mundo antiguo, Córdoba, 267-278.

Wiegels, R. (1985): Die Tribusinschriften des Römischen Hispanien, Berlin. 